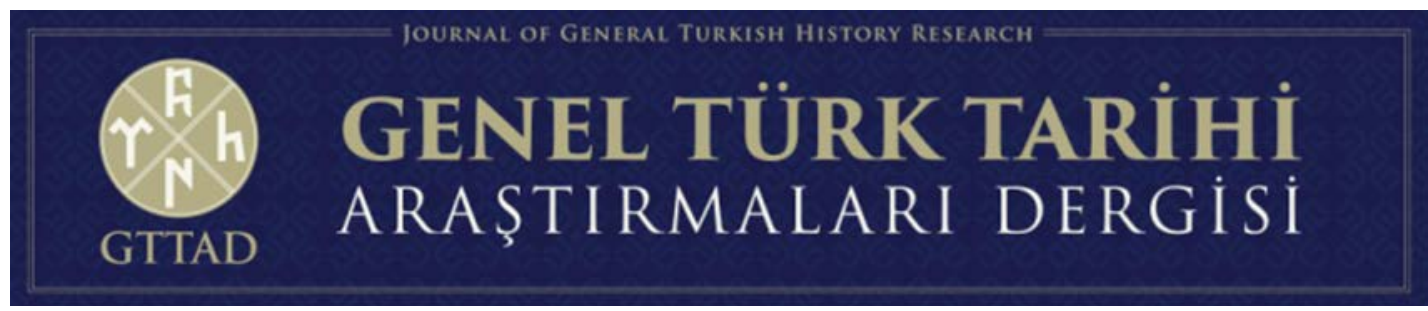

Cilt/Volume 3, Sayı/Issue 6, Temmuz/July 2021, ss. 309-318.

Geliş Tarihi-Received Date: 27.05.2021 Kabul Tarihi-Accepted Date: 06.07.2021

ARASTTIRMA MAKALESI - RESEARCH ARTICLE

\title{
THE IMPORTANCE OF KIPCHAK TURKISH TEXTS WITH ARMENIAN LETTERS IN TURKISH HISTORY
}

\section{ZELİHA TUĞUZ*}

\section{ABSTRACT}

The Kipchaks named by Russians as "Polovets, Polovtsi Palawtz", Byzantines and Latins "Cumanos, Kumanon, Cumanus, Komani, Cuman”, Germans "Falben, Falbe, Falones”, French "Coman, Poles, Planner”, Czechs "Plawci” other Western nations and Armenians "Khiptchakhs, Khartes, Hartes”, Georgians “Kivjak", Hungarians "Kun, Paloch”, Chinese "K'inch'a, Kinchak”, Mongols “Kibcag”, Muslim nations "Kipchak, Kipchak, Kipchaks" have an important place among the Turkish people who came from Central Asia to the north of the Black Sea, the Balkans and Central Europe. Although they occupied a wide area in today's Ukraine, Moldova, part of Russia, Belarus and Poland, they could not emerge as a political union and could not establish a Kipchak state in the "Deşt-i Kıpçak", also known as "Kipchak Steppe" since the beginning of the 12th century. The Kipchaks, intertwined with different nations and cultures in such a wide geography, left many written texts using the alphabets of different nations due to their inability to establish a political unity. Arabic letters were used in texts related to literature, religion, military and veterinary medicine in the Mamluk field in the 14th and 15th centuries, while Armenian letters were used in texts written on many different subjects such as history, law, religion, literature, language and chemistry in the north of the Black Sea in the 16th and 17th centuries.

In this study, information was given about the texts written in Kipchak Turkish with Armenian letters in the north of the Black Sea between 1521-1699. The scanning model was used as a method and the texts, consisting of approximately 30,000 pages, which is preserved in different libraries around the world, has been tried to be presented. Especially chronicles, historical documents and records were evaluated through Turkish history. It is stated that the texts provide first-hand data opportunity for those working in fields such as General Turkish History and Ottoman History. As the texts are reliable and original, they may strengthen Turkish historical studies. The texts are both well organized and accessible, so these features may provide great convenience in historical studies. In addition, it was underlined that the fact that the chronicles, which are a firsthand source for social sciences and humanities, have different manuscripts, can make an important contribution to questioning and analyzing information. In the conclusion part, it was discussed why the texts which about history, law, religion, literature, language, chemistry; written in Kipchak Turkish by using Armenian letters have an important place in Turkish history.

Keywords: Kipchak Turkish with Armenian Letters, Kipchak Historical Chronicles, Kipchak History, Historical Kipchak Dialect

\section{ERMENI HARFLİ KIPÇAK TÜRKÇESİ METINLERININ TÜRK TARIHHINDEKİ ÖNEMI}

\section{ÖZ}

Rusların "Polovets, Polovtsi Palawtz", Bizanslıların ve Latinlerin "Kumanos, Kumanon, Cumanus, Komani, Kuman", Almanların "Falben, Falbe, Falones", Fransızların "Koman, Lehler, Planci", Çeklerin "Plawci" diğer Batılı milletlerin ve Ermenilerin "Khiptchakhs, Khartes, Harteş", Gürcülerin "Kivcak", Macarların "Kun, Paloç”, Çinlilerin“K’inch’a, Kinçak”, Moğolların "Kibcag”, Müslüman milletlerin“Kıpçak, Kıfşak, Hıfcak” olarak adlandırıldığı Kıpçaklar, Orta Asya’dan Karadeniz’in kuzeyine, Balkanlar’a ve Orta Avrupa'ya büyük gruplar halinde gelen Türk boyları arasında önemli bir yere sahiptir. 12. yüzyılın başlarından Kıpçaklar “Kıpçak Bozkırı” olarak da adlandırılan Deşt-i Kıpçak’ta; bugünkü Ukrayna, Moldova, Rusya’nın bir

\footnotetext{
* Öğr. Gör. Dr., Mersin Üniversitesi, Eğitim Bilimleri Fakültesi, Türkçe Eğitimi Anabilim Dalı, E-Posta: zelihatuguz@gmail.com, ORCID ID: 0000-0003-0977-8858
} 


\section{THE IMPORTANCE OF KIPCHAK TURKISH TEXTS WITH ARMENIAN LETTERS IN TURKISH HISTORY}

kısmı ve Romanya'nın bir kısmını kaplayan çok geniş bir alanda geniş bir sahayı işgal ettikleri hâlde siyasi bir birlik olarak ortaya çıkamamışlar, bir Kıpçak devleti kuramamışlardır. Bu kadar geniş coğrafyada farklı milletler ve kültürlerle iç içe olan Kıpçaklar, siyasi bir birlik sağlayamamalarının da etkisiyle farklı milletlerin alfabelerini kullanarak yazılı birçok eser bırakmıştır. 14. ve 15. yüzyıllarda Memluk sahasında edebiyat, din, askerlik ve baytarlıkla ilgili eserlerde Arap harflerini kullanılırken 16. ve 17. yüzyıllarda Karadeniz'in kuzeyinde tarih, hukuk, din, edebiyat, dil, kimya gibi birçok farklı konuda yazılan metinlerde Ermeni harflerini kullanmışlardır.

$\mathrm{Bu}$ çalışmada 1521-1699 yılları arasında Karadeniz'in kuzeyinde Ermeni harfli Kıpçak Türkçesi ile yazılmış metinler hakkında bilgi verilmiştir. Yöntem olarak tarama modeli kullanılan ve dünya çapında farklı kütüphanelerde muhafaza edilen yaklaşık 30.000 sayfadan oluşan metinler tanıtılmaya çalışılmıştır. Özellikle vakayinameler, tarihi belgeler, kayıtlar Türk tarihi açısından değerlendirilmiştir. Metinlerin Genel Türk Tarihi, Osmanlı Tarihi gibi alanlarda çalışanlara birinci elden veri imkânı sağladığı, güvenilir ve geçerli olmaları sebebiyle bu metinlerin Türk tarihi çalışmalarına güç katacağı, metinlerin hem derli toplu oluşu hem de erişime açık oluşu tarih çalışmalarında büyük bir kolaylık sağlayabileceği gibi noktalar üzerinde durulmuştur. Ayrıca sosyal ve beşeri bilimler için ilk elden kaynak olan vakayinamelerin farklı nüshaları oluşunun, bilgileri sorgulama ve analiz etme noktasında önemli bir katkı sağladığının altı çizilmiştir. Sonuç bölümünde tarih, hukuk, din, edebiyat, dil, kimya ile ilgili konularda Ermeni harfli Kıpçak Türkçesiyle yazılan metinlerin Türk tarihinde neden önemli bir yere sahip olduğu tartışılmıştır.

Anahtar Kelimeler: Ermeni Harfli Kıpçak Türkçesi Metinleri, Kıpçakça Tarihi Vakayinameler, Kıpçak Tarihi, Tarihi Kıpçak Lehçesi.

\section{INTRODUCTION}

Kipchaks ${ }^{1}$ have spread over a wide geography in Eurasia, Eastern Europe and Africa throughout history. This region, which is called Cumania/Comania in the Western world, and Deşt-i Kıpçak in the Islamic world; it extends from the Volga to the Eastern Europe and Balkans. ${ }^{2}$ Kipchaks have undeniable effect on the political, economic, cultural life of West Siberia, Central Asia, South Russia, Eastern Europe, Hungary and the north of the Balkans, the Caucasus, and Northeast Africa. ${ }^{3}$ Although the Kipchaks spread to such a wide geography, they could not establish a permanent political union. Because of this, they could not establish a common, standard and sustainable written language tradition.

With the collapse of the Armenian Bagrat State in the 11th century, the Armenians started to migrate to the north of the Caucasus and settled in Crimea. ${ }^{4}$ In the first half of the 13th century, as a result of the Mongol armies capturing the city of Ani and forcing the Armenians to migrate, the Armenians first went to the north of the Black Sea and from there to the west.

It is estimated that the Kipchak-Armenian contact started in the 11th century. This contact has developed in the 13th-14th centuries to form a common language of speech in Crimea. At the end of the 14th century, the migrations continued in the same direction because of the Mongols' raids. There have been changes in the ethnic structure of settlements such as Karasubazar, Gözleve, Simferopol, İnkerman, Solhat, especially Kefe and Sudak. ${ }^{5}$

The Armenian colonies that came to Ukraine ${ }^{6}$ are named as "Mankerman” in Kipchak Turkish texts with Armenian letters in Kiev. According to the texts, it was stated that the Armenians spoke Kipchak and that they swore in Kipchak while acquiring citizenship at the local Armenian court. In the texts, the speakers of this language expressed the language they spoke in three ways, first as "xıpçah language", then "our language" and "tatar language". 7

Austrian Turcologist Friedrich von Kraelitz-Greifenhorst first mentioned Kipchak Turkish texts with Armenian letters in 1912. Later, the studies on these texts were carried out by the Ukrainian Academy of Sciences. Ukrainian Turcologist Agatangel Efimoviç Krımskiy (1871-1942), a member of the Academy,

\footnotetext{
${ }^{1}$ For Kipchak naming in different languages, see Fatma Kaçar Manay, Kıpçak Göçleri, Sinop Üniversitesi Sosyal Bilimler Enstitüsü (Yayımlanmamış Yüksek Lisans Tezi), Sinop 2019, s. 1.

${ }^{2}$ Akdes Nimet Kurat, IV-XVIII. Yüzyıllarda Karadeniz Kuzeyindeki Türk Kavimleri ve Devletleri, Murat Kitabevi, Ankara 1992, s.69-99.

${ }^{3}$ Peter Golden, Türk Halkları Tarihine Giriş, çev. Osman Karatay, Karam Yayınları, Ankara 2002, s. 225.

${ }^{4}$ Omeljan Pritsak, "Ermeni Kıpçakçası”, Tarihî Türk Şiveleri, çev. Mehmet Akalın, Türk Kültürünü Araştırma Enstitüsü Yayınları, Ankara 1988, s. 123.

${ }^{5}$ Jean Deny, L'armeno-Coman Et Les “Ephemerides” De Kamieniec (1604-1613), Otto Harrassowitz, Wiesbaden 1957, s. 7-9.

${ }^{6}$ For the infornation about Armenian colonies in Ukraine in the 15th-19th centuries see Yaroslav R Daşkeviç, Armyanskiye kolonii na

Ukraine v istoçnikax i literature XV-XIX vekov (istoriografiçeskiye oçerk), İzdatel'stvo akademii nauk Armyanskoy SSR., Yerevan 1962.

${ }^{7}$ Aleksandr Garkavets, Kıpçakskoe Pismennoe Nasledie I, Katalog i Teksti Pamyatnikov Armyanskim Pismom, Almaty 2002 , s. 7.
} 


\section{ZELİHA TUĞUZ}

introduced these texts to the world of science in more detail by his work titled "Turk ix movi ta literature" and accepted this community as Turkish. ${ }^{8}$

\section{Kipchak Texts with Armenian Letters}

Kipchak Texts with Armenian letters that were written in Kiev, Kamenets, Suçov, Seret, Lviv, Lutsk and Vladimir regions between the 16th and 17th centuries are examined under six headings in terms of their subjects: ${ }^{9}$

\section{Historical chronicles \\ 2. Legal documents and court records \\ 3. Philological texts \\ 4. Religious texts \\ 5. Literary texts \\ 6. Texts on natural sciences ${ }^{10}$}

The texts, which include historical chronicles, legal documents and court proceedings, prayer books, Psalms, life stories of the saints, sermons, St. Paul's letters, philological texts, are preserved in the following libraries: Vienna Mechitarist Monastery, Vienna National Library, Venice Mechitarist Library, Paris Bibliotheque Nationale, Wroclaw Ossolineum Library, Krakow Chartorysky Museum, Yerevan Matenadaran and Leiden University Library.

28 Law registers, Kamanets-Podolsk Armenian Court's registers and "Tayni Filosofskogo Kamnya (Secrets of the Philosopher's Stone)” written by Andrey Torosovich in Kiev; a dictionary and 26 individual documents in Lviv; 9 manuscripts of the church about philology in Yerevan; a dictionary, a book on the life of the saints and a Psalter in St. Petersburg; 3 dictionaries, Law Book, 13 legal books on Christianity and the court, court registers, Psalters, prayer books, 3 sermon books of Vartabed Anton in Vienna; 10 manuscripts including the Psalters, prayer books, court registers, chronicles in Venice; 11 manuscripts including the Psalter, prayer books, calendar and the Law Book from 1528-1604 in Krakow, Warsaw and Wroclaw; Psalter, calendar, books regarding legends and chronicles about the wise Hikar in Paris; Algış Bitigi (perhaps the first book published in Turkish in 1618) in Leiden.

\subsection{Historical Chronicles}

Three chronicles written in Kipchak Turkish with Armenian letters have been recorded so far: "Kamenets chronicle", "Venetian chronicle" and "Polish chronicle".

\subsubsection{Kamenets Chronicle}

The Kamenets chronicle was written by Armenian priest Agop between 1582 and 1621 in both Armenian and Kipchak. His brother Aksent made corrections, additions and completed the book in 1650-1652. In the

\footnotetext{
${ }^{8}$ Hülya Kasapoğlu Çengel, “Ermeni Harfli Kıpçak Türkçesi”, Dil Araştırmaları, Sayı: 10, Bahar 2012, s. 24.

${ }^{9}$ Garkavets and Hurşudyan is referenced in the information about the content and tags of these texts: Aleksandr Garkavets, Eduard Hurşudyan, Armenian-Qypchaq Psalter Written by Deakon Lussig From Lviv 1575/ 1580, Almaty 2001, s. 595-600

For more information about Kipchak Texts with Armenian letters, see Aleksandr Garkavets, Virmeno-Klpchatski rukopisi v Ukraini, Virmenii, Rosii: Katalog, Kiev 1993; Aleksandr Garkavets, Kıpçakskoe Pismennoe Nasledie II, Pamyatniki Duhovnoy Kulturi Karaimov, Kumanov- Polovtsev i Armyano- Kıpçakov, Almaty 2007; Aleksandr Garkavets, Klpçakskoe Pismennoe Nasledie III, Kıpçakskiy Slovar po Armyanopismennım Pamyatnikam XVI-XVII Vekov, Almaty 2010; Timofey Grunin, I. Dokumentı na polovetskom yazıke XVI v. (Sudebniye aktı kamenetspodol'skoy armyanskoy obşçinı) Transkriptsiya perevod predislovie vvedenie grammatiçeskiy kommentariy i glossariy T. I. Grunina (Pod. redaktsiyey E. V. Sevortyana. Statya Ya. R. Daşkeviça), İzdatel'stvo "Nauka", Moskva 1967; Edmond Schütz, "On the Transcription of Armeno-Kipchak”, Acta Orientalia Academiae Scientiarum Hungaricae, 1961, p. 139-161; Edmond Schütz, “An ArmenoKipchak Print from Lvov (A.D. 1618)”, Acta Orientalia Hungarica, T. 13, , 1961, p. 123-130; Edmond Schütz, An Armeno-Kipchak Chronicle on the Polish-Turkish Wars in 1620-21, Akadémiai Kiadó, Budapest 1968; Edward Tryjarski, Arméno-Kipchak Texts in the Alchemical Treatise by Andrzej Torosowicz (17th Century), Warsaw 2005; Edward Tryjarski, Dictionnaire arméno-kiptchak d'apres trois manuscrits des collections viennoises, fascicule 1, A-H, Warszawa 1968; Edward Tryjarski, Dictionnaire arméno-kiptchak d'apres trois manuscrits des collections viennoises, fascicule 2, I-K, Warszawa 1968; Edward Tryjarski, Dictionnaire arméno-kiptchak d'apres trois manuscrits des collections viennoises, fascicule 3, X-0, Warszawa 1969; Edward Tryjarski, Dictionnaire arméno-kiptchak d'apres trois manuscrits des collections viennoises, fascicule 4, P-Z, Warszawa 1972.

${ }^{10}$ For the infornation about the vocabulary of these works, see Zeliha Tuğuz, Ermeni Harfli Kıpçak Türkçesinde Isimlerin Kavram Alanları, Erciyes Üniversitesi Sosyal Bilimler Enstitüsü (Yayımlanmamış Doktora Tezi), Kayseri 2019.
} 


\section{THE IMPORTANCE OF KIPCHAK TURKISH TEXTS WITH ARMENIAN LETTERS IN TURKISH HISTORY}

Kamenets chronicle, Aksent also mentioned that his brother Agop was struggling to establish churches and his grief over the early death of priest Agop. In the chronicle, the events in Pravobrejniy, Western Ukraine, Moldova, Wallachia and the events in Kamenets-Podolsk, including the years 1430-1652 explained in detail. In the Kipchak chapter, information was given about the tension between Polish and Ottoman, the Battle of Hotin (1620-1621) and the Battle of Tsetsora (in Moldova between 17 September-7 October 1620). The first Kipchak record of the chronicle belongs to the presidential election of the Kamenets Armenian community in January 1611 and the last record of the chronicle belongs to the death of Vartabed Mesrob from Kefe on May 12, 1622.

There are two manuscripts of the Kamenets chronicle: Venice and Paris manuscripts. The long manuscript is kept at number 1700 in the Armenian Mekhitarist Library in Venice. The Kipchak chapter of this long manuscript describes the events that took place between 1611-1624. This manuscript was published by Armenian priest Ghevond Alişan in both Armenian and Kipchak with the title "Kamenits", Taregirk’ hayots' Lehastani ew Rumenioy” (Chronicle of Kamenets, Poland and Romanian Armenians) in Venice in 1896.

The Paris manuscript of the Kamenets chronicle is a short manuscript and is registered at the Paris National Library at number 194. This chronicle includes events from 1611 to 13 November 1613.

\subsubsection{Venice and Poland Chronicles}

Both Venice and Poland chronicles are in Paris Bibliotheque Nationale and take place on pages 60-65 of manuscript 194. These two chronicles are very short. They give information about the events from the birth of the Prophet Jesus until 1537. They also contain interesting information about the activities of the religious communities in Liviv. There are some parts from Venice manuscript no. 1700: ${ }^{11}$

Tv. 1063 [1614], junis 15, hankün. Bügüngi künnü pan hetman Žolk'evskiy, voyvoda Kiyovskiy, starosta Barskiy, türk çavuşu bilä vitac'a boldu hala artına. Da bar edi halada 4 ḩazah. Ol 4 hazahnı kesärlär edi çavuş alnına. 12 "Date: 1063 [1614], June 15, Wednesday. Today Commander Zholkevsky, Voivode of Kiev, Barsky headman met with the Turkish sergeant behind the castle. And there were 4 Kazaks in the castle. These 4 Kazaks were to be executed in front of the sergeant."

Tv 1063 [1614], sebdemper 25, yıhpaşkün. Tatar elçisi keldi Kameneckä, haysı ki başhışlar bilä ketiyir edi kşonžegä pan Krakovskiygä, da birgäsinä 12 atlı tatar bar edi. “Date: 1063 [1614], September 25, Monday. The Tatar ambassador came to Kamenets, bringing gifts to Pan Krakowski and was accompanied by 12 Tatar cavalry". 13

Tv. 1063 [1614], nojemper 4, aynakün. Nemiç elçisi ketti korol'dan Türkkä. Atı Tarkovskiy. “The date: 1063 [1614], November 4, Friday. The Polish ambassador went from the kingdom to the Turkish lands. His name was Tarkovsky". ${ }^{14}$

Tv. 1063 [1614], nojemper 15. Hotin halasın korol' rozkazat etti Olah biyinä Tomşaga oddat etmä, nedä ki oddat ettilär.’Date: 1063 [1614], November 15. The king ordered that Hotin Castle be given to the Moldavian Lord Tomsha and they gave it". ${ }^{15}$

Tv. 1063 [1614], tegdemper 18, yıhkün. Bedros der Krikor og̉lu, der Jovsepnì hardaşı, elçiliyin ketti Olah biyinä Tomşaga neçik cesardan, alay že bizim korol'dan 3-çi Zigmunttan. "The date: 1063 [1614], December 18, Sunday. Bedros, the son of the venerable Krikor, brother of the venerable Joseph, went as an ambassador to the Moldovan Lord Tomsha both from the Caesar and from our king Sigismund III”. ${ }^{16}$


Ivaşkovskiy edi, da asrı yarar igitlär edi. Da alayže 5 konfederatnı da birgälärinä kestilär. Haysı ki padşah dekreti bilä kestirdi podstarosciy Kaveckiy Türk padşahınıり çavuşu alnına bu 2 ḩazahnı. Da 2 ḩazahnı boş etti çavuş boġozları bilä. Zera barı 4 edi. Da soyra ol 2 keskän hazahlarnı kömdülär asrı körklü Nemiç habahı çıharı, procäsiya bilä, Božemuka yanına, hayda ki kömüptürlär özgä hazahlarnı- Muha da Kalinanı. "The date: 1064 [1615], June 30, Friday. They killed the Kazaks, whose names are one Shulga, and the other Ivashkovsky, and they were very valuable brave men. And with them 5 confederates were executed. By order of the king, the

\footnotetext{
${ }^{11}$ Aleksandr Garkavets, Kipçakskoe Pismennoe Nasledie I, Katalog i Teksti Pamyatnikov Armyanskim Pismom, Almaty 2002, s. 536-537.

12 Tarih: 1063 [1614], 15 Haziran, Çarşamba. Bugün Sayın Komutan Zholkevski, Kiev Voyvodası, Barski yöneticisi kalenin arkasındaki Türk çavuşu ile görüştü. Ve kalede 4 Kazak vardı. Bu 4 Kazak, çavuşun önünde idam edilecekti.

${ }^{13}$ Tarih: 1063 [1614], 25 Eylül, Pazartesi. Tatar elçisi Efendi Krakowski'ye hediyelerle getirerek Kamenets'e geldi ve yanında 12 atlı Tatar vardi.

${ }^{14}$ Tarih: 1063 [1614], 4 Kasım, Cuma. Polonya elçisi krallıktan Türk topraklarına gitti. Adı Tarkovski idi.

15 Tarih: 1063 [1614], 15 Kasım. Kral, Hotin Kalesi'nin Moldavya Bey’i Tomşa'ya verilmesini emretti ve verdiler.

${ }^{16}$ Tarih: 1063 [1614], 18 Aralık, Pazar. Saygıdeğer Josef'in kardeşi olan saygıdeğer Krikor'un oğlu Bedros, hem Cesar hem de kralımız III. Zigmunt tarafından Moldova Lordu Tomşa'ya elçi olarak gitti.
} 


\section{ZELİHA TUĞUZ}

headman of Kavetsky had these 2 Kazaks executed in front of a Turkish king's sergeant. And sergeant freed 2 Kazaks from execution. There were 4 in total. Then these 2 executed Kazaks were buried very magnificently, with a procession, outside the Polish city gate where other Kazaks, Mukha and Kalina, were previously buried. ${ }^{17}$

Tv. 1064 [1615], okosdos 31. kiçaynakün. Tatar hanı asrı köp adam bilä kirdi Nemiç veliyätinä Okrayina bilä, da ketti çah Ilôvga yuvuh, da haytıp keldi Kamenec tibinä, Doluşka yanına qoşun hoydu, da barça salalarnı, da humnalarnı, da tüzdä biçänlärni küvürdü. Evet şähärdän p'ehota, alayže özgä ohvotnıylar- neçik ermeni, alay nemiç, orus- çıhıp birgälärinä, potıkacc'a boluy edilär, alayže toptan haladan da şähärdän üstlärinä uruy edilär. Haysı ki keldilär şähär tibinä aş zamanına, da ruşicc'a boldular yarımkeçädä, da barıp Turlunu keçtilär Hotin tibinä. Evet asrı ulu doyumluh çıhardılar birgälärinä. “The date: 1064 [1615] August 31, Thursday. Tatar Khan invaded Poland through Ukraine with a large crowd, he reached Lviv, turned back and approached Kamenets, set up a camp near the Doluzhka (river) and burned all the villages, the threshing field and the straw in it. Yes, the infantry and other volunteers- both Armenians and Poles, Ukrainians- came out of the city and fought with them. They fired cannons at them from the fort and the city. They approached the city at lunchtime, left at midnight; crossed the Dniester by the Hotin coast. And they brought with them a great booty. ${ }^{18}$

\section{Legal Documents and Court Records}

Many documents containing the legal regulations and procedures of the Western Ukrainian Armenian community have reached today. The pages of the legal documents and court records reached today ehceed 18 thousand. Most of the documents consisting of marriage agreements, minutes, testaments, birth registration, religious matters, judicial records are kept in the archives of Lviv, Vienna and Warsaw. Among these documents, there are many ehcerpts from lost records and documents.

\subsection{Court Records}

Financial, administrative or judicial records such as forensic cases, birth records, religious matters, and cash registers in the Armenian community were recorded in minute books or in separate minutes. The minutes of the Kamenets-Podolsk Armenian Court are of great importance in these records. One volume of the 32 volumes of documents belonging to the Armenian community is in Kipchak Turkish. These documents were brought to Kiev from Kamanets and kept in the Kiev Old Records Archives of the Kiev University from the 16th to the 19th century. Some of these documents were burned in the fire in 1944. Kırımskiy instructed his student Timofey Ivanoviç Grunin, who had previously worked on the monuments written in Kipchak Turkish with Armenian letters, to process these documents in Kiev, but Grunin's work was confiscated when Grunin became passionate in 1933. Grunin focused on Kamenets-Podolsk tehts in his doctoral thesis "Ego meste sredi tyurkskihlazov" (Kipchak Language. Its Place Among Turkish Languages), which he later completed. Grunin published 298 minutes of the Armenian court of Kamenets-Podolsk, which is thought to have disappeared in the Second World War, covering the years 1559-1567, with its Russian translation, transcription, language features and dictionary of the tehts "Dokumentı na polovetskom Alase HVI v. (sudebnıe aktı kamanets-podol'skoy armyanskoy obşçin1)” in Moscow in 1967.

\subsection{Töre Bitiki (The Law Book)}

"Töre Bitigi" 19 was written by Mihtar Gosh between 1184-1213, was translated from Armenian to Latin in 1518-1519, then from Latin to Polish, and from Polish to Kipchak in 1523 by order of King Sigizmund of Poland. There are three known manuscripts:

1. Wrostlaw manuscript is numbered 1916 and dated 1528 in the Ossolinski National Institute in Wrotslaw,

2. Liviv manuscript is numbered 176 and dated 1568 in Paris National Library,

3. Kamenets manuscript is numbered 468 and dated 1575 in the Armenian Mehitarist Library in Vienna.

\footnotetext{
${ }^{17}$ Tarih: 1064 [1615], 30 Haziran [10 Temmuz], Cuma. İsimleri Shulga ve Ivashkovski olan Kazakları öldürdüler ve onlar çok değerli yiğitlerdi. Ve onlarla birlikte 5 konfederatı idam edildi. Kavetsky'nin reisi kralın emriyle bu 2 Kazak'ı bir Türk padişahının çavuşu önünde idam ettirdi. Ve çavuş 2 Kazak'ı idamdan kurtardı. Toplamda 4 tane vardı. Daha sonra idam edilen bu 2 Kazak, daha önce diğer Kazakların, Mukha ve Kalina'nın gömüldüğü Polonya kapısının dışında, çok görkemli bir şekilde gömüldü.

${ }^{18}$ Tarih: 1064 [1615] 31 Ağustos, Perşembe. Tatar Han, büyük bir kalabalıkla Polonya'yı Ukrayna üzerinden işgal etti, Lviv'e ulaştı ve geri dönerek Kamenets'e yaklaştı, Doluşka [nehri] yakınında bir kamp kurdu ve tüm köyleri, harman yerini ve içindeki samanları yaktı. Evet, piyade ve diğer gönüllüler- hem Ermeniler, hem Polonyalılar hem de Ukraynalılar- şehirden çıkıp onlarla savaştı ve kaleden ve şehirden onlara toplarla ateş ettiler. Yemek (öğle) vakti şehre yaklaşırken, gece yarısı ayrıldılar ve Hotin kıyısından Dinyester'i geçtiler. Ve yanlarında çok büyük bir ganimet getirdiler.

${ }^{19}$ Armiyanskiy Sudebnik
} 


\section{THE IMPORTANCE OF KIPCHAK TURKISH TEXTS WITH ARMENIAN LETTERS IN TURKISH HISTORY}

“Töre Bitigi” consists of three parts. In the introduction, the origin of the book and the purpose of its writing were ehplained. It was mentioned that the Gregorians were criticized a lot due to the fact that the laws were not implemented in writing in the early days, and that the laws were obliged to be written down in time. Then, information was given by referring to some of the rules and stories of Christianity, which were written such as the power and source of the laws, the qualities of the judge, how the testimony should be, the nature of the oath, disregard for the court of the atheists. After mentioning that some parts of these rules could be reorganized and even new laws could be added on the condition of keeping up with the changing time and space and not departing from the concept of justice, the second chapter has begun.

In the second chapter, which includes the laws on world affairs; how the inheritance law of the rulers will be, according to what conditions the successor will be determined, who has the authority such as public works or ehecution of ehecution offenders, how the prize obtained from wars will be shared, who is subject to tah, how much from whom... Issues such as tah charges were ehplained. Following 124 items related to life were given; many areas of law such as criminal law, family law, inheritance law, property law, commercial law, labor law, law of obligations, public law was discussed. In the third section, which was added to Töre Bitiki later, the rules to be obeyed by people who have legal issues and various legal regulations were ehplained. ${ }^{20}$

\subsection{Philological Tehts}

Two Kipchak grammar books written in 1581 and 1613 in Lviv, several ehplanatory dictionaries and five dictionaries are the tehts that ehamined under this title. The first of the grammar book is kept in Yerevan Matenadaran Library with registration number 2267, the second book is kept in Vienna Mekhitarist Library with registration number 84. Dictionaries are available in Lviv University Library, State Library in San Petersburg, National Library in Vienna, Armenian Mehitarist Library, Yerevan Matenadaran Library.

The first part of the manuscript no. 51 in the Lviv University Library, manuscript no. 8 at the State Library in San Petersburg, manuscripts no. 3 and 311 in the National Library in Vienna, manuscripts no. 84 in the Armenian Mehitarist Library in Vienna, a dictionary no. 2267 are the tehts in this group.

\subsection{Religious Tehts}

Five Psalms in Vienna, Krakow, Paris, Venice, St. Petersburg libraries and archives, Apostle Paul's letters, Vartabed Anton's four sermon books, Algış Bitigi (consists of nine prayer books, one of which is in the Netherlands), the life stories of the saints, a few books on astrology, an Easter calendar and the Turkish calendar with twelve animals are the tehts ehamined under this heading. ${ }^{21}$

\subsection{Literary Tehts}

The only work in this category is "İstoriya mudrogo Hikâra" known as "The Hikâyesi of the Wise Hikar" or "The Legend about the Wise Akir", which tells about the wise words and the legendary lives of the saints. It is a didactic work that gives information about Kipchaks. ${ }^{22}$

It is located between pages 54-62 of the manuscript registered at number 468 in the Armenian Mekhitarist Library in Vienna.

\subsection{Tehts on Natural Sciences}

The teht titled “Taynı filosofskogo kamnya”(Secrets of the Philosopher's Stone) ${ }^{23}$ written by Andrey Torosovic between 1626-1631 is the only known work in this field. The work includes chemical ehperiments, horticulture, fruit growing, breeding and the work of leading scientists of the Ancient and Middle Ages.

\section{CONCLUSION}

\footnotetext{
${ }^{20}$ Hakan Korkmaz, Töre Bitiki Grameri, Erciyes Üniversitesi, Sosyal Bilimler Enstitüsü (Yayımlanmamış Yüksek Lisans Tezi), Kayseri 2014, s. 11 .

${ }^{21}$ Vienna Mekhitarist Library no: 143 (p. 98-146), Vienna Mekhitarist Library no: 525 (p. 210-246); Yerevan Mekhitarist Library no: 2403 (p. 272-302); Venice Mekhitarist Library no: 1126 (p. 518-535), Venice Mekhitarist Library no: 1750 (p. 589 ); Krakow U.M. no: 2412 (p. 771-801).

${ }^{22}$ Nadejda Chirli, Ermeni Kıpçakça Dualar Kitabı Alğı̧̧ Bitigi, SOTA Yayınları, Haarlem Netherlands 2005 , s. 21.

${ }^{23}$ For more information, see Edward Tryjarski, Arméno-Kipchak Texts in the Alchemical Treatise by Andrzej Torosowicz (17th Century), Warsaw 2005.
} 


\section{ZELİHA TUĞUZ}

As in all branches of science, history does not stay where it is. Every document, every record takes the science of history one step further. Powerful and dominant nations are nations that have documents and information ${ }^{24}$.

The importance of documents in historical research is a fact known by all researchers. Especially chronicles are important in terms of both the history of nations and revealing the official opinion in the ehamination of any subject. Because events are in the past, the historian cannot observe the events he/she is working on. What remains to the historian is the evidence, that is documents. Historical chronicles, legal documents and court records written in Kipchak Turkish with Armenian letters are capable of supporting and strengthening the studies in Turkish history.

While the events are happening, it is not possible to record all of them in documents. Even if recorded, not all of them have survived to the present day. This fact makes the lack of historical documents and therefore historical data inevitable. Apart from observing the events with incomplete data, it is not possible to reconstruct them as they were in the past. Kipchak Turkish tehts with Armenian letters offer those who work in fields such as General Turkish History and Ottoman History the opportunity to ehamine these documents and compare them with the documents they work with, to overcome the gaps and deficiencies in Turkish history studies.

The document is the traces of the events. The historian reconstructs events by following these traces. The building process is directly related to the validity and security of the document. The document is written later or has been tampered with affects the reconstruction of the event ${ }^{25}$. The fact that, these Kipchak chronicles and documents which written day-to-day make studies reliable and valid. In other words, the use of daily written Kipchak chronicles and documents may support the reliability and validity of Turkish historical studies.

As stated before, during the history search, what the historian has is not the original events, but the documents left over from them. Most of the time, these documents were often scattered and fragmented. Well organization of these Kipchak chronicles and documents is another positive feature of these documents. Also, some historical documents are inaccessible or very difficult to access. The accessibility of all these Kipchak tehts provides great convenience for researchers who want to benefit from these records.

Even when an event is fully documented, these documents provide information on only a small part of the historical event. It is also not possible to record all aspects of the event correctly. As we approach today, visual data such as films, photographs, postcards, places where the event took place and verbal data such as witnesses of the event are used in historical research to support the document and generate new information. But these possibilities are not available for 16th-17th century historical studies. From this point of view, tehts with different manuscripts are a great chance for researchers who have an inquisitive understanding of history. Different manuscripts make an important contribution to questioning and analysing historical information. EHKT tehts offer researchers this opportunity.

The most important feature of chronicles is that they are a first-hand resource for social sciences and humanities. The EHKT tehts are among the valuable resources to be used in determining and writing the national and common histories of not only Turkish people, but also various nations such as Russia, Ukraine, Belarus, Moldova, Romania, Poland, Armenia and Georgia that have established independent states. Today, researchers from these countries may refer to Kipchak tehts to ehamine, identify and evaluate social sciences issues while establishing their own national archives.

Chronicles and historical documents, registers written in Kipchak Turkish with Armenian letters, which are located in the ancient libraries of Europe and Asia today, are first-hand sources due to the fact that the events are written day by day and have an important place in the field of Turkish history as well as in the field of Turkish language.

\section{BIBLIOGRAPHY}

ACUN, Fatma, “Tarihin İnşası Sürecinde Belge ve Kullanımı” Cumhuriyet Döneminde Türkiye’hhde Tarihçilik ve Tarih yayıncılı̆̆ Sempozyumu, Ankara 2010.

CHİRLİ, Nadejda, Ermeni Kıpçakça Dualar Kitabı Algıış Bitigi, SOTA Yayınları, Haarlem Netherlands 2005.

\footnotetext{
${ }^{24}$ Fatih Rukancı, “Arşiv Belgelerimizin Uluslararası Önemi”. Uluslararası Asya ve Kuzey Afrika Çalışmaları Kongresi Bildiriler: Müzeler, Arşivler, Kütüphaneler, Yayınevleri, Telif Haklarl, ICANAS 38 10-15 Eylül 2007, Ankara, Atatürk Kültür, Dil ve Tarih Yüksek Kurumu, Ankara 2009, s. 207.

${ }^{25}$ Fatma Acun, "Tarihin İnşası Sürecinde Belge ve Kullanımı” Cumhuriyet Döneminde Türkiye’xxde Tarihçilik ve Tarih yayıncıllğ Sempozyumu, Ankara 2010, s.93.
} 


\section{THE IMPORTANCE OF KIPCHAK TURKISH TEXTS WITH ARMENIAN LETTERS IN TURKISH HISTORY}

DAŞKEVIÇ, Yaroslav R., Armyanskiye kolonii na Ukraine $v$ istoçnikah i literature $H V-H I H$ vekov (istoriografiçeskiye oçerk), İzdatel'stvo akademii nauk Armyanskoy SSR., Yerevan 1962.

DENY, Jean, L'armeno-Coman Et Les “Ephemerides” De Kamieniec (1604-1613), Otto Harrassowitz, Wiesbaden 1957.

GARKAVETS, Aleksandr, Kıpçakskoe Pismennoe Nasledie I, Katalog i Teksti Pamyatnikov Armyanskim Pismom, Almaty 2002.

GARKAVETS, Aleksandr, Klpçakskoe Pismennoe Nasledie II, Pamyatniki Duhovnoy Kulturi Karaimov, Kumanov- Polovtsev i Armyano- Kipçakov, Almaty 2007.

GARKAVETS, Aleksandr, Klpçakskoe Pismennoe Nasledie III, Kipçakskiy Slovar po Armyanopismennim Pamyatnikam HVI-HVII Vekov, Almaty 2010.

GARKAVETS, Aleksandr, Virmeno-Kipchatski rukopisi v Ukraini, Virmenii, Rosii: Katalog, Kiev 1993.

GARKAVETS, Aleksandr, HURŞUDYAN, Eduard, Armenian-Qypchaq Psalter Written by Deakon Lussig From Lviv 1575/ 1580, Almaty 2001.

GOLDEN, Peter, Türk Halkları Tarihine Giriş, çev. Osman Karatay, Karam Yayınları, Ankara 2002.

GRUNIN, Timofey I. 1967. Dokumentı na polovetskom yazıke HVI v. (Sudebniye aktı kamenetspodol'skoy armyanskoy obşçinı) Transkriptsiya perevod predislovie vvedenie grammatiçeskiy kommentariy i glossariy T. I. Grunina (Pod.redaktsiyey E. V. Sevortyana. Statya Ya. R. Daşkeviça). Moskva: İzdatel'stvo "Nauka", Moskova 1967.

KAÇAR MANAY, Fatma, Klpçak Göçleri, Sinop Üniversitesi Sosyal Bilimler Enstitüsü (Yayımlanmamış Yüksek Lisans Tezi), Sinop 2019. 2012.

KASAPOĞLU ÇENGEL, Hülya, "Ermeni Harfli Kıpçak Türkçesi”, Dil Araştırmaları, Sayı: 10, Bahar

KORKMAZ, Hakan, Töre Bitiki Grameri, Erciyes Üniversitesi, Sosyal Bilimler Enstitüsü (Yayımlanmamış Yüksek Lisans Tezi), Kayseri 2014.

KURAT, Akdes Nimet, IV-HVIII. Yüzylllarda Karadeniz Kuzeyindeki Türk Kavimleri ve Devletleri, Murat Kitabevi, Ankara 1992.

PRITSAK, Omeljan, "Ermeni Kıpçakçası”, Tarihî Türk Şiveleri, çev. Mehmet Akalın, Türk Kültürünü Araştırma Enstitüsü Yayınları, Ankara 1988.

RUKANCI, Fatih, "Arşiv Belgelerimizin Uluslararası Önemi”. Uluslararası Asya ve Kuzey Afrika Çalışmaları Kongresi Bildiriler: Müzeler, Arşivler, Kütüphaneler, Yayınevleri, Telif Hakları, ICANAS 38 10-15 Eylül 2007, Ankara, Atatürk Kültür, Dil ve Tarih Yüksek Kurumu, Ankara 2009.

SCHÜTZ, Edmond, “An Armeno-Kipchak Print from Lvov (A.D. 1618)”, Acta Orientalia Hungarica, T. 13, , 1961, p. 123-130.

SCHÜTZ, Edmond, An Armeno-Kipchak Chronicle on the Polish-Turkish Wars in 1620-21, Akadémiai Kiadó, Budapest 1968.

SCHÜTZ, Edmond, “On the Transcription of Armeno-Kipchak”, Acta Orientalia Academiae Scientiarum Hungaricae, 1961, p. 139-161.

TRYJARSKI, Edward, Arméno-Kipchak Tehts in the Alchemical Treatise by Andrzej Torosowicz (17th Century), Warsaw 2005.

TRYJARSKİ, Edward, Dictionnaire arméno-kiptchak d'apres trois manuscrits des collections viennoises, fascicule 1, A-H, Warszawa 1968.

TRYJARSKI, Edward, Dictionnaire arméno-kiptchak d'apres trois manuscrits des collections viennoises, fascicule 2, I-K, Warszawa 1968.

TRYJARSKİ, Edward, Dictionnaire arméno-kiptchak d'apres trois manuscrits des collections viennoises, fascicule 3, H-0, Warszawa 1969. 


\section{ZELİHA TUĞUZ}

TRYJARSKİ, Edward, Dictionnaire arméno-kiptchak d'apres trois manuscrits des collections viennoises, fascicule 4, P-Z, Warszawa 1972.

TUĞUZ, Zeliha, Ermeni Harfli Kıpçak Türkçesinde İsimlerin Kavram Alanları, Erciyes Üniversitesi Sosyal Bilimler Enstitüsü (Yayımlanmamış Doktora Tezi), Kayseri 2019. 
THE IMPORTANCE OF KIPCHAK TURKISH TEXTS WITH ARMENIAN LETTERS IN TURKISH HISTORY 